Research

\title{
Spatio Temporal Distribution of Anthrax in Sulawesi 2015-2018
}

\author{
Titis Furi Djatmikowati ${ }^{*}$, Dini Wahyu Yudianingtyas ${ }^{2}$, Haeriah ${ }^{1}$ \\ ${ }^{1}$ Bacteriology Laboratory of Maros Disease Investigation Center, Directorate General of Livestock and Animal Health, \\ Ministry Agriculture of Indonesia \\ ${ }^{2}$ Epidemiology Laboratory of Maros Disease Investigation Center, Directorate General of Livestock and Animal Health, \\ Ministry Agriculture of Indonesia \\ ${ }^{*}$ Corresponding author: titis.furi@gmail.com \\ Submitted 6 November 2019, Accepted 22 December 2019
}

\begin{abstract}
Three among five Provinces (South Sulawesi, West Sulawesi and Gorontalo) in Sulawesi island, Indonesia are endemic area of anthrax disease. The aim of this study was to describe the dynamic of anthrax during 2015-2018 and identified risk area in Sulawesi. We determined case of anthrax disease from passive-active surveillance data Disease Investigation Center Maros (DIC Maros) during 2015-2018. Spatial distribution describe by mapping using Quantum Geographic Information System (QGIS), the temporal distribution describe using epidemic curve and we calculated the proportion of animal infected of anthrax. There were thirty-three cases of anthrax spreaded into three Provinces in Sulawesi, there were twenty one cases in South Sulawesi (63.6\%), nine cases in Gorontalo (27.3\%) and three cases West Sulawesi (9.1\%). There were eleven cases (33.3\%) in 2015, fifteen cases (45.5\%) in 2016, four cases (12\%) in 2017 and three cases (6\%) in 2018. Anthrax occured respectively in dry season in South Sulawesi and Gorontalo, different with West Sulawesi anthrax occured in rainy season. The proportion of the animal infected were $87 \%$ in cattle, $7 \%$ in horse, $3 \%$ goat and $3 \%$ in deer. Vaccination of anthrax in South Sulawesi and Gorontalo should be conducted in May; in Polewali Mandar, West Sulawesi in Februari.
\end{abstract}

Keywords: anthrax, spatio-temporal, distribution, Sulawesi, Indonesia

\begin{abstract}
ABSTRAK
Tiga dari lima Provinsi di pulau Sulawesi, Indonesia (Sulawesi Selatan, Sulawesi Barat dan Gorontalo) merupakan daerah endemis antraks. Tujuan dari studi ini untuk medeskripsikan dinamika penyakit antraks dan mengidentifikasi daerah berisiko tinggi di pulau Sulawesi selama 2015-2018. Gambaran kasus antraks diperoleh berdasarkan data surveilans aktif dan pasif Balai Besar Veteriner Maros selama 2015-2018. Distribusi spatial (pemetaan) dengan menggunakan Quantum Geographic Information System (QGIS), distribusi temporal dengan menggunakan kurva epidemik dan memproporsikan hewan teinfeksi antraks dalam prosentase (\%). Tiga puluh tiga kasus antraks menyebar di tiga Provinsi di Sulawesi, dua puluh satu kasus di Sulawesi Selatan (63.6\%), sembilan kasus di Gorontalo ( 27.3\%) dan tiga kasus di Sulawesi Barat (9.1\%). Kasus antraks pada tahun 2015 sebanyak sebelas kasus (33.3\%), limabelas kasus pada tahun 2016, empat kasus (12\%) pada tahun 2017 dan tiga kasus (6\%) pada tahun 2018. Kasus antraks di Sulawesi Selatan dan Gorontalo sebagian besar terjadi pada musim kemarau selama 2015-2018, berbeda dengan Sulawesi Barat terjadi pada musim hujan. Proporsi hewan peka yang terinfeksi antraks $87 \%$ terjadi pada sapi, $7 \%$ pada kuda, 3\% pada kambing dan 3\% pada rusa. Vaksinasi antraks Sulawesi Selatan dan Gorontalo sebaiknya dilakukan bulan in Mei; di Polewali Mandar, Sulawesi Barat bulan Februari.
\end{abstract}

Kata kunci: antraks, spatio-temporal, distribusi, Sulawesi, Indonesia 


\section{INTRODUCTION}

Anthrax is a bacterial disease in herbivores and several poultry species, caused by Bacillus anthracis. This bacteria is able to spores form in non-conducive conditions, resistant to disinfectants, heat, cold, chemicals and irradiation. The Bacillus anthracis will be change into vegetative form if provides same nutrition they need such as in media or in the host's body it then multiplied and can kill the host ( $\mathrm{J}$. Glenn et al, 2005; Risa et al, 2012). Anthrax is zoonotic, transmission to human dependent of the exposures route (gastrointestinal, pulmonary, cutaneous and meningitis). Clinical symptoms in humans $95 \%$ are cutaneus anthrax, case fatality rate gastrointestinal form 5-75\%, and meningitis form had bad prognosis (Kementerian Kesehatan, 2017;WHO, 2008). Refer to Risa et al (2012) cited from the report Ministry of Health during 2002-2007 the CFR of human death caused anthrax was $7.2 \%$.

As in Faizal et al (2012) had been calculated considerable economic losses caused anthrax estimated round up to 4.293.012 US\$ per year in South Sulawesi. The previous study in 2010-2014 anthrax in South Sulawesi Province spread into seven district (Maros, Gowa, Makassar, Pangkep, Barru, Takalar, Bone dan Sidrap) described the trends of distribution of anthrax in South Sulawesi spreaded into new areas (Wiwik et al, 2015). South Sulawesi Province have a high potentialy source of livestock too, the population of livestock around 1.434.998 (https:// sulselprov. go.id, 2017) and support the other Province in Sulawesi even the other island, so its must be an alert of anthrax spreading to the other area.

There is need to identify risk area of the anthrax disease in Sulawesi to support effective decisionmaking control strategies (particularly vaccination program) and preventive recommendations to reduce anthrax in high-risk area.

\section{MATERIAL AND METHODS}

\section{Study Design, Study Site and Population}

We conducted a retrospective study using all data collected from active - passive surveillance collected by the Maros Disease Investigation Centre (DIC) of anthrax 2015-2018 in Sulawesi. We filtered the investigation data from active surveillance and combined with the passive surveillance data that indicated the outbreak were occurance. Climate condition data during 2015-2018 estimated that in Sulawesi dry season was from June until November and rainy season was from December until May.

\section{Operational Definitions}

Active surveillance specimen collected from field by DIC Maros and the passive surveillance spesimen collected by the Animal Heath District Officers in Sulawesi. Types of specimen were blood, organ and soil wich contaminated by blood from animal that showed clinical sign such as suddenth death and bleeding of eye, ear or anus. All specimens were tested at Bacteriology laboratory to identify Bacillus anthracis. The epidemiological unit that observed was the area (province, district, subdistrict and village) in Sulawesi.

\section{Data Analysis}

We analyzed the data descriptively to determine time, place and animal. Spatial distribution descriptively analyzed by mapping using Quantum Geographic Information System (QGIS), the temporal distribution describe using epidemic curve and we determined animal infected of anthrax by calculate the the proportion by using precentages.

\section{Ethical Consideration}

Disease Investigation Center Maros (DIC), as technical unit of the Ministry of Agriculture of Idonesia has official mandate to carry out surveillance, investigation and laboratory testing animal diseases in the east region of Indonesia. The Animal Health District Officers in Sulawesi as collaborative partners of DIC Maros to cooporate the national mandate. In this study using two data with obtained from laboratory result data of anthrax diagnosis from DIC Maros. For this reason, no additional ethical clearance was demeed necessary for any study activities.

\section{RESULTS}

We analyzed anthrax case from January 2015 to December 2018 in Sulawesi there were thirty-three cases of anthraks consist of eleven cases $(33.3 \%)$ in 2015 , fifteen cases $(45.5 \%)$ in 2016 , four cases (12\%) in 2017 and three cases (6\%) in 2018. We identified epidemic curve and anthrax cases in dry season and rainy season from each province (Figure 1 and 2).

The spatial distribution of anthrax in 2015 (Figure 3) showed that anthrax cases only reported on in South Sulawesi Province. During periode 2015-2018, South Sulawesi Province had the highest number reported of anthrax case, outbreak spreaded into six districts: Maros, Makassar, Gowa, Pare-Pare, Sidenreng, Rappang and Pinrang (Figure 3-6). 


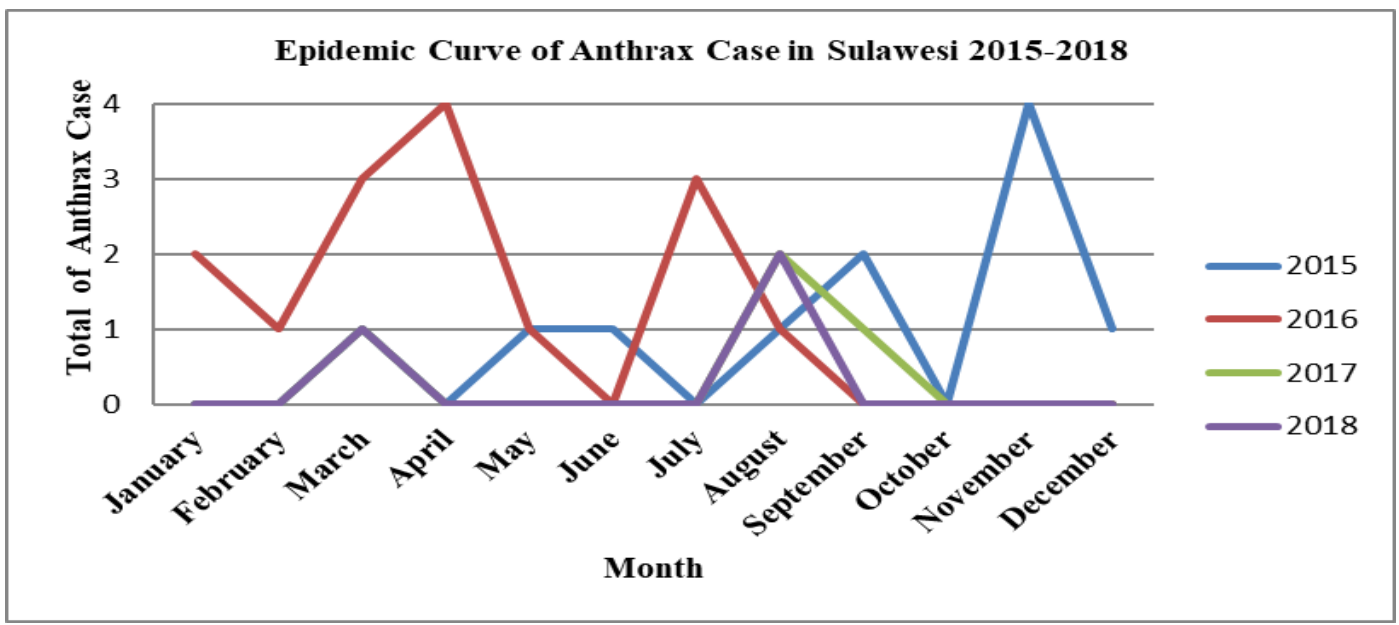

Figure 1

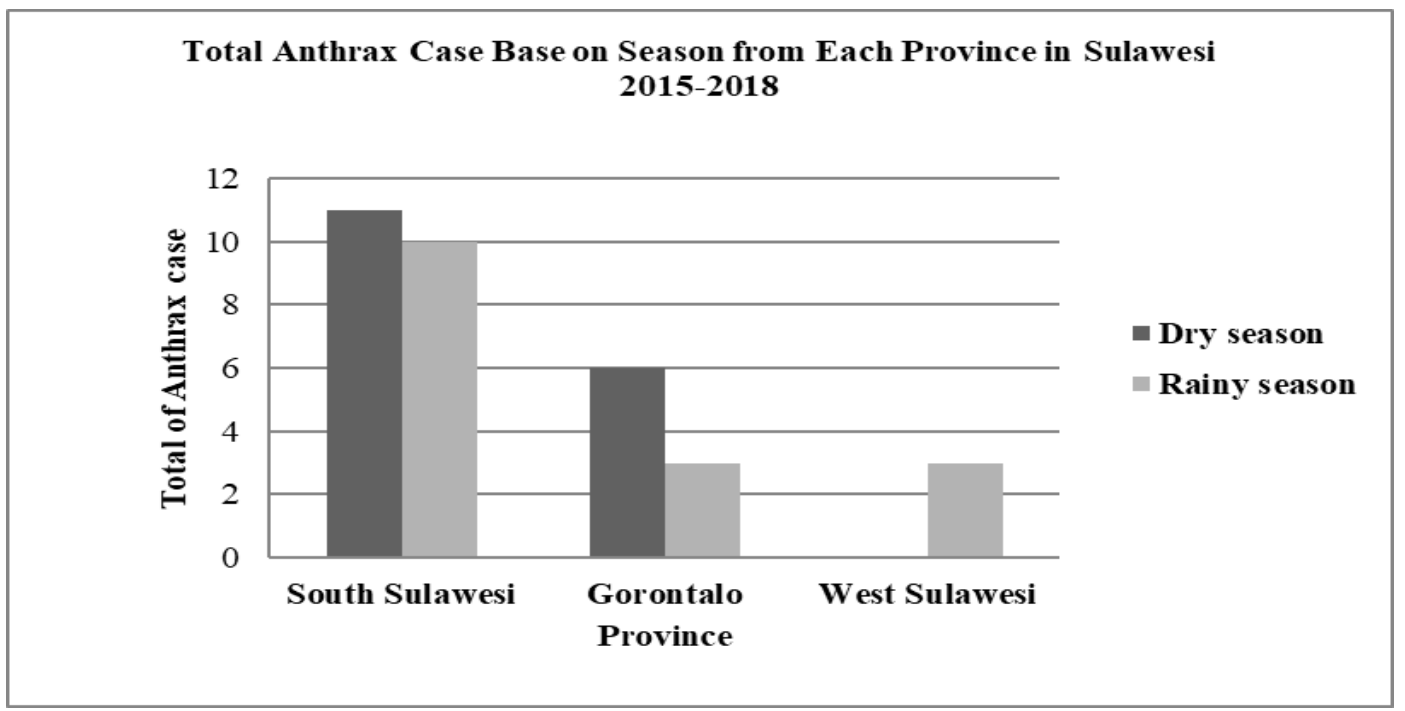

Figure 2

In 2016 there was anthrax outbreak in Pinrang, South Sulawesi Province (previously free area of anthrax). Anthrax outbreak locations were two villages, Malimpung and Padangloang from Patampanua subdistrict (Figure 4). In the same year anthrax spreaded into West Sulawesi and Gorontalo Province. Three districts in Gorontalo Province were Gorontalo district, Gorontalo city and Bone Bolango district were reported, and in 2017 anthrax spreaded into two new villages that were Tenilo and Bolihuangga, Limboto subdistrict, Gorontalo district (Figure 5). First case of anthrax in West Sulawesi reported from Polewali Mandar district (Figure 4). Anthrax outbreak occured in Gattungan village, Campalagian subdistricts and Bumiayu village, Wonomulyo subdistricts, cases reported only in 2016, in 2017-2018 there was no anthrax report from West Sulawesi Province.

Anthrax cases report based on the susceptible host, in catlle reported from three provinces, horse cases reported from Maros district, and deer case from Gowa dsitrict (South Sulawesi Province). Anthrax in goat reported from Polewali Mandar districts, West Sulawesi Province (Figure 7).

\section{DISCUSSION}

The temporal distribution in this study describe Figure 1 in Sulawesi categorized in seasonal trend (cycle trend) according to (Trusfield et al, 2008) showed a fluctuation in the periodic incidence of a disease related with density, management, infectious agent resistance, vector dynamics and other ecological factors. We identified there is different season between each infected area of anthrax in Sulawesi. In West Sulawesi Province in this case Polewali Mandar district had two peak of rainfall after March dan September, so we can identified anthrax case in Polewali Mandar district infected in rainy season (Hartina\&Usman, 2017). Anthrax case in South Sulawesi and Gorontalo Province mostly reported in dry season, according Titis et al (2019) 
10 | Djatmikowati et al.

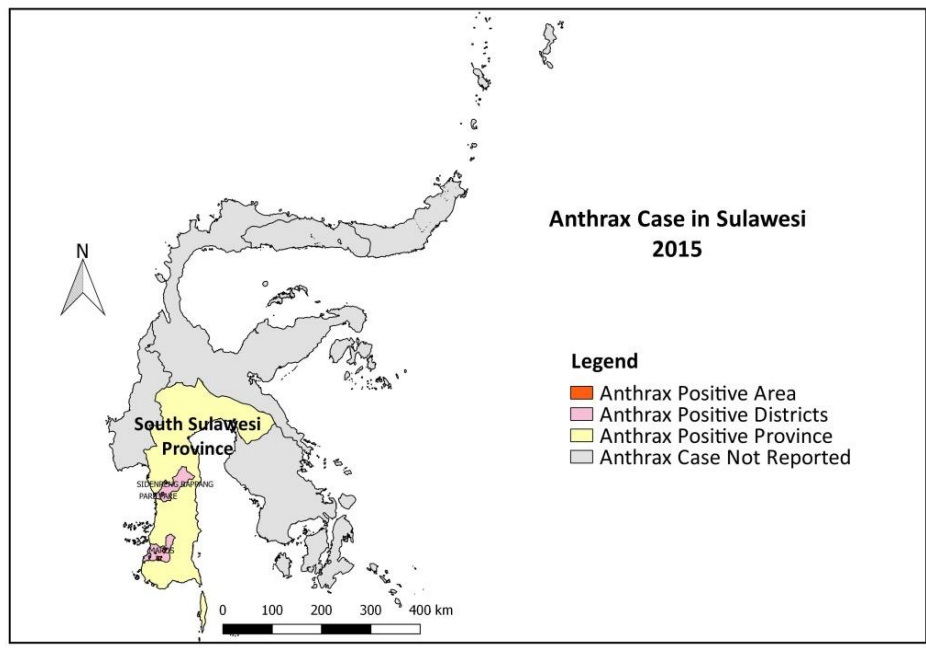

Figure 3

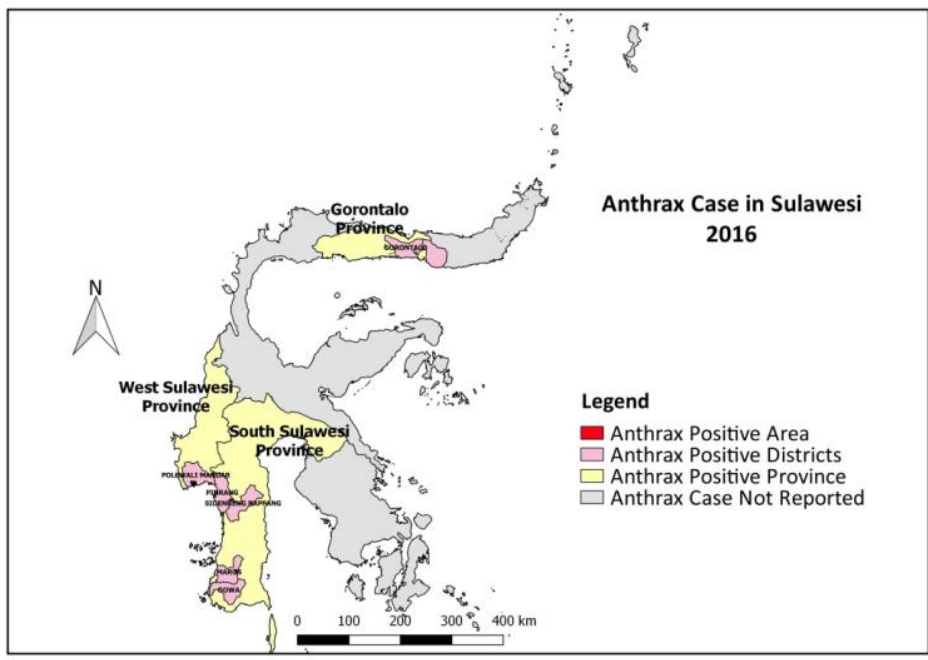

Figure 4

dry season significantly associated to anthrax occurences, in South Sulawesi Province.

According Turnbull et al (1998) the incidence of anthrax related to temperature, rain and drought conditions. The climate can affect directly or indirectly to the behavior of animals in terms of contact with spores, in the dry season animals eats grass to the root containing spore infested soil or moving cattle tends to look further for grass to lower areas especially the water source areas because the grass in the area is more fertile. Anthrax outbreaks in the West Nusa Tenggara Province occured at the end and beginning of the year during the rainy season (Eny\&Wahyuwardani, 1998). The other study anthrax occured during the rainy season because livestock start eating new grass / plants infested with anthrax spores. Water flow evaporated to the lower areas can collect spores from previous anthrax cases and concentrated in the region and increase the potential for transmission (Anak A.G.P et al., 2011).
South Sulawesi Province have a high potentialy source of livestock to support the other Province in Sulawesi even the other island. Increased movement of animal suported by lack of understanding of the community about circulation animal product that contaminated anthrax spore had contributted to spreading (Anak A.G.P et al., 2011). According to the study before (Wiwik et al, 2015) described the trends of distribution of anthrax in South Sulawesi Province spread into new areas. Spatial distribution in this study spatial distribution of anthrax disease showed increased significancy of anthrax occurences in Sulawesi [Figure 3-6]. Should be awarness to making decision policy about trading the animal to other free area of anthrax disease.

The majority species of animal affected of anthrax is cow reported from three anthrax positive Province, although horses, goats and deer had been reported. Anthrax vaccination must be conducted was approximately 6-12 months to them all animal 


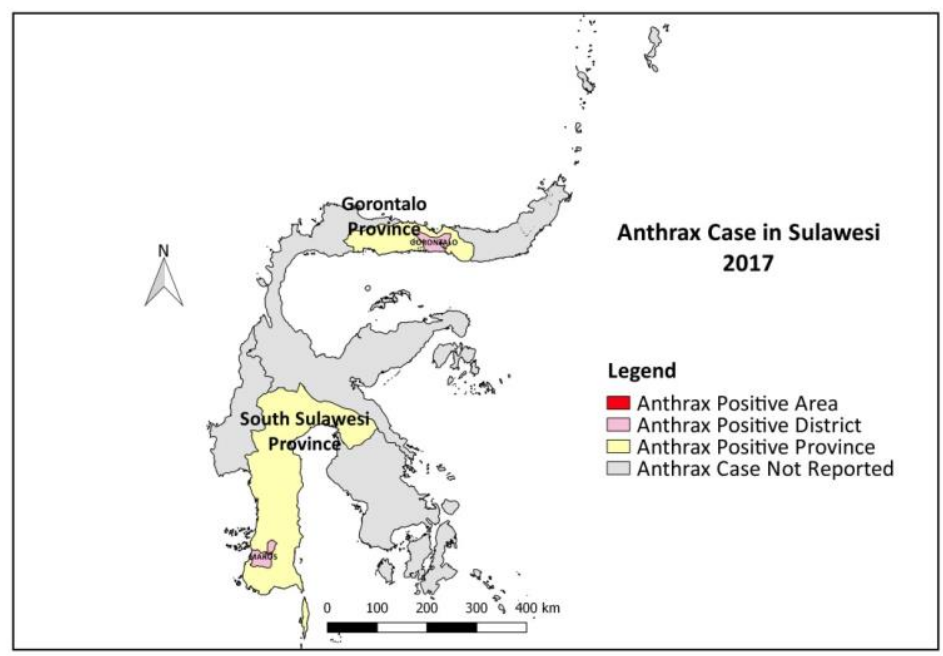

Figure 5

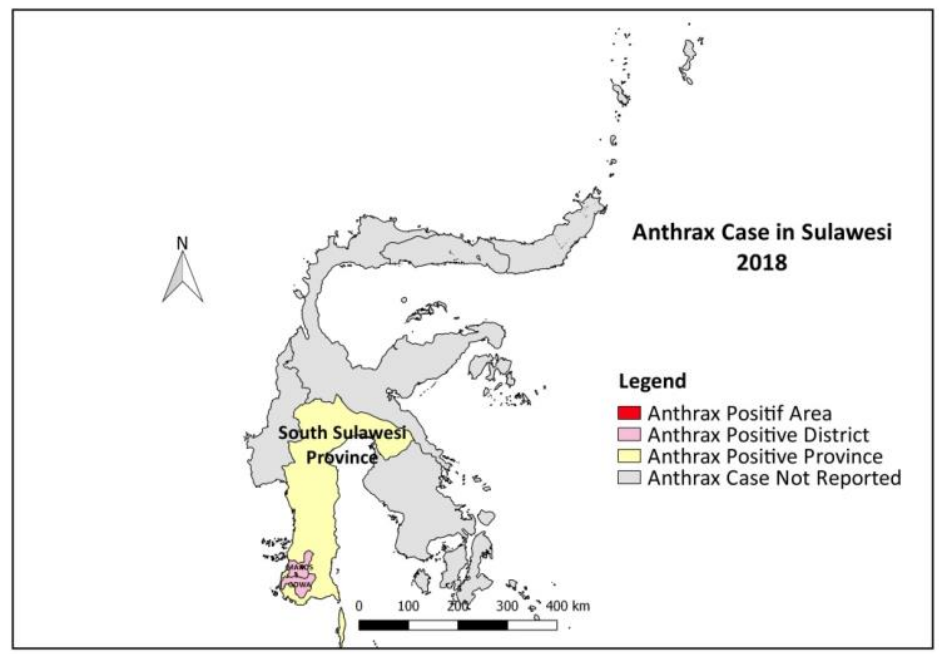

Figure 6

need to regularly repeated especially in anthrax endemic areas (Kementerian Pertanian, 2016; Turnbull et al, 1998) to increase animal immunity and vulnerable reduce economic losses due to animal mortality. Immunity to anthrax will occur between 10 days to 14 after vaccination, in order to maximize protective immunity against anthrax infection, the vaccine must be given at least a month before the estimated outbreak time and repeated at the estimated period of the outbreak (Mafany et al., 2008).

Regarding on the temporal distribution in 20152018 the highest anthrax cases periode in South Sulawesi Province and Gorontalo Province was in dry season, so vaccination program in endemic areas could be carried out one month before estimated of dry season. Different with Polewali Mandar district West Sulawesi Province anthrax occurence in the begining of rainy season, vaccination program in endemic areas could be carried out one month before estimated of the rainy season.

Limitation of this study is the analysis based on number and time of anthrax cases and not considering possible related to risk factors which could be contributed to the anthrax spreading in Sulawesi. Temporal distribution can estimate the outbreak occurence to do preventive and control of the the anthrax disease in Sulawesi.

Our study decribed the distribution of anthrax in several provinces in Sulawesi during the 2015-2018 tended extend to the northern part of Sulawesi island. High risk area of anthrax in South Sulawesi Province were Gowa, Maros, Pinrang, Sidrap, Makassar and Pare-Pare district. High risk area of anthrax in Gorontalo province were Gorontalo city, Gorontalo and Bone Bolango district. High risk area of anthrax in West Sulawesi was Polewali Mandar district. Temporal distribution can estimate the outbreak occurence to do preventive and control of the 


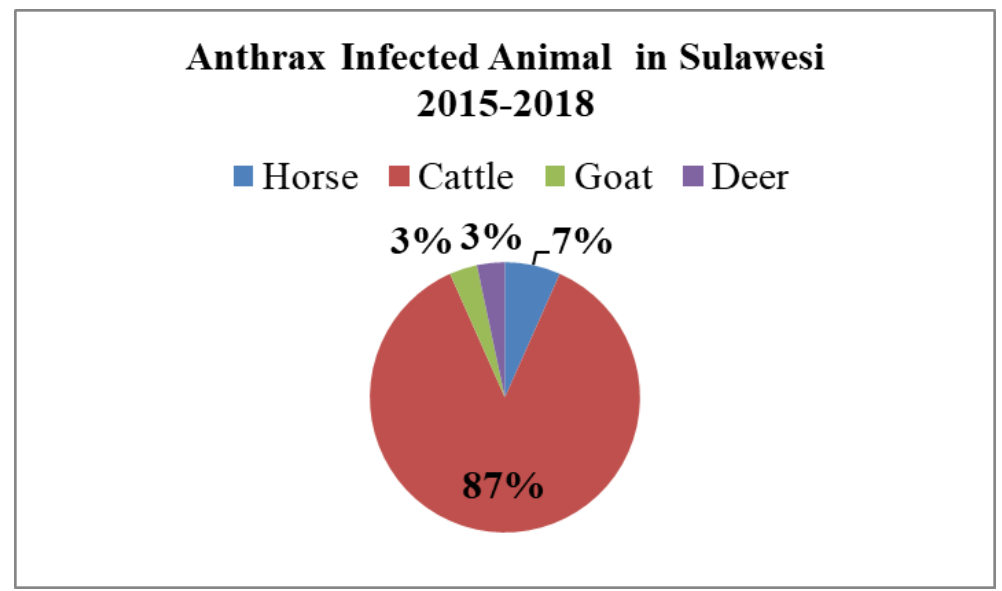

Figure 7

anthrax disease in Sulawesi. To reduce incidence of anthrax outbreak in South Sulawesi and Gorontalo Province, vaccination should be conducted in May. In Polewali Mandar, West Sulawesi Province vaccination should be conducted in Februari.

\section{ACKNOWLEDGEMENTS}

Thanks to Directorate of Animal Health, Indonesia Ministry of Agriculture, Funding donor CDC, Alert Asia Foundation, Director of DIC Maros, all staff and District officer who contributed for specimens collection and laboratory testing, Mentors and all Indonesia Field Epidemiology Veterinary participants.

"All authors declare that there are no conflicts of interest".

\section{REFERENCES}

Anak AGP, Marseni BR, Ni Made A, Agus S, Said KD, Erwin K, Rini H, 2011. Antrax di Nusa Tenggara. Direktorat Jenderal Peternakan dan Kesehatan Hewan Kementerian Pertanian - ASCIAR, ISBN : 978-079-628-024-7, hal.51-67 Percetakan Swasta Nulus. Denpasar - Bali.

Eny M, S. Wahyuwardani, 1998. Pola kasus Antraks pada ternak di Propinsi Nusa Tenggara Barat, 3(1). 39-46 Jurnal Ilmu Ternak Veteriner, Bogor.

Faizal Z, Bagoes P, Ferra H, 2012. Model Analisa Kerugian Ekonomi Akibat Penyakit Anthraks Pada Sapi Potong di Sulawesi Selatan. Buletin Informasi Kesehatan Hewan dan Kesehatan Masyarakat Veteriner, vol.11, no.1, Balai Besar Veteriner Maros, Direktorat Jenderal Peternakan dan Kesehatan Hewan, Kementerian Pertanian Republik Indonesia
Hartina W, Usman, 2017. Analisis karakteristik dan klasifikasi curah hujan di Kabupaten Polewali Mandar, Jurnal Sainsmat, ISSN 2579-5686 (Online), vol.VI, no.1, hal.15-27 Jurnal Sainsmat, Maret 2017 , http://ojs.unm.ac.id/index.php/sainsmat https://id.climate-data.org/location/3646/. At 31 July 2017

https://nasional.kompas.com/read/2015/09/12/07423 901/Musim.Kemarau.yang.Panjang

https://gorontalo.antaranews.com/berita/25591/bmk g-wilayah-utara-gorontalo-masuk-musimkemarau

https://gorontaloprov.go.id/informasi/berita/provgorontalo/puncak-musim-hujan-di-gorontalobervariasi

https://sulselprov.go.id/upload/files/Populasi\%20Ter nak\%20Sulawesi\%20Selatan\%2020142017.pdf http://www.bmkg.go.id/berita/?p=mei-juni-julimemasuki-awal-musim-kemarau-2017\&lang=ID

J.Glenn S, Karen WP, Veterinary Microbiology. 2005. Bacterial and Fungal Agents of Animal Disease. Elsevier Saunders, Missouri.

Kementerian Pertanian, 2016. Pedoman Pengendalian dan Pemberantasan Penyakit Antraks. Kementerian Pertanian Direktorat Jenderal Peternakan dan Kesehatan Hewan.

Kementerian Kesehatan, 2017. Dirktorat Jenderal Pencegahan dan Pengendalian Penyakit, Surat edaran tentang kewaspadaan penyakit Antraks, no.HK.02.02/IV/152/2017, Jalan Percetakan Negara no.29, kode pos 223, +62214247608 , Jakarta Pusat, Indonesia, 2017

Mafany NM, Neil WD, Charles LS, Margaret LK, 2008. Risk factors associated with Anthrax outbreak in animals in North Dakota 2005 : A retrospective case control study. Public Health Reports, vol. 123 : 352-359. 
Risa SD, Lintang D, M. Arie W, 2012. Risk factor of human Anthrax in Karangmojo, Klego, Boyolali district 2011. Faculty of Public Health Diponegoro University, Public health journal, vol. 1, no.2, p:454-465, publised at http:// ejournals1.undip. ac.id/index.php/jkm.

Thrusfield, Veterinary Epidemiologi. 2008. Third Edition. ISBN 978-1-405-15627-1. Blackwell Publishing. p:137.

Titis FD, Dini WY, Faizal Z, Haeriah, Suryani GU, 2019. Anthrax in South Sulawesi 2015-2017", in press dalam Rapat Pertemuan Ilmiah 21-24 Juni 2019.

Turnbull PCB, R Böhm, O Cosivi, M Doganay, ME Hugh-Jones, DD Joshi, MK Lalitha, V de Vos
Kruger National. 1998. Guidance Survaillance and Control of Anthrax in Human and Animal, Third Edition, WHO, Centre of Applied Microbiology and Researche, Porton Down Salisburry, UK.

WHO, 2008. Antraks in Human and Animal. Fourth Edition, World health Organization Press, AppiaAvenue-Geneva-Switzerland.

Wiwik D, Titis FD, Bagoes P, 2015. Distribusi antraks di Sulawesi Selatan 2010-2014. prosiding rapat pertemuan ilmiah dan investigasi kesehatan hewan, Direktorat Jenderal Peternakan dan Kesehatan Hewan, ISSN 2087-1279, vo.1 no.6, hal.315 